\title{
Heparin-Binding Epidermal Growth Factor-Like Growth Factor in Hippocampus: Modulation of Expression by Seizures and Anti- Excitotoxic Action
}

\author{
Lisa A. Opanashuk, ${ }^{1}$ Robert J. Mark, ${ }^{1,2}$ Julie Porter, ${ }^{1}$ Deborah Damm, ${ }^{3}$ Mark P. Mattson, ${ }^{1,2}$ and \\ Kim B. Seroogy 1 \\ ${ }^{1}$ Department of Anatomy and Neurobiology and 2Sanders-Brown Research Center on Aging, University of Kentucky, \\ Lexington, Kentucky 40536, and ${ }^{3}$ Scios Inc., Mountain View, California 94043
}

The expression of heparin-binding epidermal growth factor-like growth factor (HB-EGF), an EGF receptor ligand, was investigated in rat forebrain under basal conditions and after kainateinduced excitotoxic seizures. In addition, a potential neuroprotective role for HB-EGF was assessed in hippocampal cultures. In situ hybridization analysis of HB-EGF mRNA in developing rat hippocampus revealed its expression in all principle cell layers of hippocampus from birth to postnatal day $(P) 7$, whereas from P14 through adulthood, expression decreased in the pyramidal cell layer versus the dentate gyrus granule cells. After kainate-induced excitotoxic seizures, levels of HB-EGF mRNA increased markedly in the hippocampus, as well as in several other cortical and limbic forebrain regions. In the hippocampus, HB-EGF mRNA expression increased within $3 \mathrm{hr}$ after kainate treatment, continued to increase until $24 \mathrm{hr}$, and then decreased; increases occurred in the dentate gyrus granule cells, in the molecular layer of the dentate gyrus, and in and

Heparin-binding epidermal growth factor-like growth factor (HB-EGF) is a member of the epidermal growth factor (EGF) family of structurally related polypeptides that include EGF, transforming growth factor- $\alpha$ (TGF $\alpha)$, amphiregulin, and betacellulin (Higashiyama et al., 1991, 1992; Watanabe et al., 1994; Barnard et al., 1995). Each family member activates the EGF receptor (EGF-R), a $170 \mathrm{kDa}$ transmembrane glycoprotein with intrinsic tyrosine kinase activity (Besner et al., 1992). HB-EGF and other EGF-R ligands are synthesized as membrane-anchored precursors that during proteolytic cleavage produce diffusible factors that mediate their effects on various cellular processes (Raab et al., 1994; Cook et al., 1995). HB-EGF and amphiregulin can be distinguished from other members of the EGF family by the presence of a heparin-binding domain, which interacts with membrane-bound heparin sulfate proteoglycans and may thereby

\footnotetext{
Received June 9, 1998; revised Oct. 9, 1998; accepted Oct. 12, 1998.

This research was supported by grants from National Institutes of Health (NS35164) and the University of Kentucky Medical Center Research Fund to K.B.S. and from National Institutes of Health (NS29001, AG05119, and NS35253) to M.P.M. L.A.O. was supported by National Institutes of Health postdoctoral fellowship NS10007. We thank Kerstin Lundgren for expert technical assistance and Dr. James Herman for helpful discussions and assistance with statistical analyses during the preparation of this manuscript.

Correspondence should be addressed to Dr. Kim B. Seroogy, Department of Anatomy and Neurobiology, University of Kentucky, 800 Rose Street, Lexington, KY 40536.

Dr. Mark's present address: Lilly Research Laboratories, CNS Research, Lilly Corporate Center, Indianapolis, IN 46285.

Copyright (C) 1998 Society for Neuroscience $\quad 0270-6474 / 98 / 190133-14 \$ 05.00 / 0$
}

around hippocampal pyramidal CA3 and CA1 neurons. At $48 \mathrm{hr}$ after kainate treatment, HB-EGF mRNA remained elevated in vulnerable brain regions of the hippocampus and amygdaloid complex. Western blot analysis revealed increased levels of HB-EGF protein in the hippocampus after kainate administration, with a peak at $24 \mathrm{hr}$. Pretreatment of embryonic hippocampal cell cultures with HB-EGF protected neurons against kainate toxicity. The kainate-induced elevation of $\left[\mathrm{Ca}^{2+}\right]_{\mathrm{i}}$ in hippocampal neurons was not altered in cultures pretreated with HB-EGF, suggesting an excitoprotective mechanism different from that of previously characterized excitoprotective growth factors. Taken together, these results suggest that HBEGF may function as an endogenous neuroprotective agent after seizure-induced neural activity/injury.

Key words: HB-EGF; hippocampus; neuroprotection; epilepsy; excitotoxicity; in situ hybridization; kainic acid; calcium enhance EGF receptor activation. HB-EGF mRNA is expressed in brain (Abraham et al., 1993), and its precise cellular distribution is beginning to be elucidated (Opanashuk et al., 1995; Mishima et al., 1996). EGF-R mRNA and protein are expressed in brain where they are localized to many different cell populations, including neurons and astrocytes (Gomez-Pinilla et al., 1988; Faundez et al., 1992; Tucker et al., 1993; Seroogy et al., 1994, 1995; Kornblum et al., 1995, 1997a). Cultured embryonic neurons and glia from rodent brain also express EGF-R (Mazzoni and Kenigsberg, 1994; Yamada et al., 1997).

Both TGF $\alpha$ and EGF promote survival and/or process outgrowth of cultured neurons from several brain regions (Morrison et al., 1987, 1988; Kornblum et al., 1990; Casper et al., 1991; Ferrari et al., 1991; Alexi and Hefti, 1993), indicating possible neurotrophic functions for EGF-R agonists. EGF promotes hippocampal long-term potentiation (Terlau and Seifert, 1989; Abe et al., 1991, 1992) and protects dopaminergic neurons against glutamate (Casper and Blum, 1995) and 1-methyl-4-phenyl1,2,3,6-tetrahydropyridine (MPTP) (Park and Mytilineau, 1992; Schneider and DiStefano, 1995) toxicity, suggesting potential neuromodulatory and neuroprotective roles for EGF-R ligands. Because HB-EGF interacts with the EGF-R, it is reasonable to consider that HB-EGF serves roles overlapping those of EGF and TGF $\alpha$.

Administration of the excitotoxin kainate to adult rodents induces seizures and a stereotyped pattern of neuronal degeneration involving limbic and cortical structures, with certain hip- 
pocampal neurons being particularly vulnerable (Nadler et al., 1978; Sperk et al., 1983; Ben-Ari, 1985). During and after seizures induced by kainate, the expression of several neurotrophic factors and cytokines increases, including NGF (Gall and Isackson, 1989; Gall et al., 1991), basic fibroblast growth factor (bFGF) (Humpel et al., 1993; Gall et al., 1994), brain-derived neurotrophic factor (BDNF) (Isackson et al., 1991; Dugich-Djordjevic et al., 1992), glial cell line-derived neurotrophic factor (GDNF) (Humpel et al., 1994), and tumor necrosis factor- $\alpha$ (TNF $\alpha$ ) (Bruce et al., 1996). Such injury-responsive neurotrophic factors and cytokines may function to prevent neuronal death (for review, see Mattson and Scheff, 1994; Mattson and Lindvall, 1997). In the present study we examined the cellular expression of HB-EGF in hippocampus, cortex, and limbic structures under basal conditions and after kainate-induced seizures, and we tested the hypothesis that HB-EGF serves an excitoprotective role.

\section{MATERIALS AND METHODS}

Animals and kainate administration. Male and female Sprague Dawley rats (Harlan Sprague Dawley, Indianapolis, IN) taken at postnatal day (P) 0, P7, P14, and P21, and adult ages ( $>60 \mathrm{~d}$ old, $n=4$ for each age) were used to examine the in situ hybridization localization of HB-EGF mRNA in hippocampus during postnatal development. Rat pups taken at the day of birth (P0) and at P7 were deeply anesthetized by hypothermia and decapitated. Animals at the other ages were deeply anesthetized with sodium pentobarbital before decapitation. The brains were rapidly dissected out, quickly frozen over dry ice, and stored at $-80^{\circ} \mathrm{C}$ until further processing. Adult ( $>60 \mathrm{~d}$ old) male Sprague Dawley rats weighing 200-250 gm were used for the kainic acid experiments. Kainate (Sigma, St. Louis, MO) was injected intraperitoneally at $12 \mathrm{mg} / \mathrm{kg}$ (dissolved in $0.9 \%$ saline, $\mathrm{pH} 7.0$ ). Control animals received an equivalent volume of saline. After kainate administration, rats were monitored for convulsive activity for $8 \mathrm{hr}$ and rated on a scale of $1-5$ as described previously (Sperk et al., 1983). Behavioral changes were evident within 30 min of kainate administration and consisted of "wet-dog shakes" followed by staring spells, forehead-nodding, forelimb myoclonus, rearing, and excessive salivation. Only animals achieving at least a level of 3 (Sperk et al., 1983) were used for analyses. At various survival periods after kainate injection $(3,6,12,24$, and $48 \mathrm{hr})$, rats $(n=3-4$ per time point) were deeply anesthetized with an overdose of sodium pentobarbital and decapitated. The brains were quickly removed and processed for mRNA or protein analyses as described below.

$R N A$ isolation and Northern blot analysis. Hippocampi were rapidly removed and placed in Trizol reagent (Life Technologies BRL, Gaithersburg, MD), and tissue was homogenized using a Polytron homogenizer. The homogenate was extracted twice with phenol/chloroform, and RNA was precipitated with isopropanol. The RNA pellet was air-dried and dissolved in DEPC-treated water, and the RNA concentration was determined by measuring OD $_{260}$. RNA $(20 \mu \mathrm{g})$ was separated by electrophoresis through a $1.2 \%$ formaldehyde-agarose gel containing ethidium bromide. RNA was then transferred to nylon membranes by vacuum transfer in $10 \times \mathrm{SSC}(0.3 \mathrm{~m}$ sodium citrate, $3.0 \mathrm{M} \mathrm{NaCl})$; RNA integrity and transfer efficiency were visualized by UV light. Membranes were prehybridized in a solution containing $2 \times$ SSC, $5 \times$ Denhardt's solution, and $2 \%$ SDS for $1 \mathrm{hr}$ at $65^{\circ} \mathrm{C}$. The antisense HB-EGF cRNA was transcribed from a pBluescript vector containing a 258 base pair Kpn fragment (bp 1-258) from the $5^{\prime}$ end of the cloned rat cDNA (GenBank accession number L05389) using T3 RNA polymerase in the presence of $\left[{ }^{32} \mathrm{P}\right]-$ UTP (cDNA was kindly provided by Judith Abraham, Scios Inc., Mountain View, CA). The hybridization reaction was allowed to proceed for $20 \mathrm{hr}$ at $65^{\circ} \mathrm{C}$ in a solution containing $50 \%$ formamide, $2 \times$ SSC, $5 \times$ Denhardt's solution, $10 \%$ dextran sulfate, $2 \%$ SDS, and the $\left[{ }^{32} \mathrm{P}\right]$-labeled probe at a concentration of $2 \times 10^{6} \mathrm{cpm} / \mathrm{ml}$. After treatment with 1 $\mu \mathrm{g} / \mathrm{ml}$ ribonuclease A (RNase) at room temperature, membranes were sequentially washed in decreasing concentrations of SSC containing $0.25 \% \mathrm{SDS}$ at $65^{\circ} \mathrm{C}$. The final wash in $0.1 \times \mathrm{SSC}$ was performed at room temperature. Membranes were exposed to X-OMAT film (Kodak, Rochester, NY) for 5-7 d, and specific hybridization was visualized by autoradiography. Membranes were stripped and reprobed with a $\left[{ }^{32} \mathrm{P}\right]-$ labeled $\beta$ actin probe (kindly provided by James Hyde, University of Kentucky, Lexington, KY). HB-EGF mRNA levels were quantified using
$\mathrm{NIH}$ Image software and normalized relative to actin mRNA levels. Control membranes were pretreated with $1 \mu \mathrm{g} / \mathrm{ml}$ RNase for $30 \mathrm{~min}$ before hybridization or were hybridized with the $\left[{ }^{32} \mathrm{P}\right]$-labeled sense cRNA HB-EGF probe (transcribed with T7 RNA polymerase). No specific hybridization was observed in either case (data not shown). As a positive control, RNA was isolated from rat lung, an organ known to express HB-EGF mRNA (Abraham et al., 1993), and hybridized with both the antisense and sense HB-EGF cRNA probes. The $2.5 \mathrm{~kb}$ transcript was detected on films from membrane probed with the antisense cRNA probe, whereas membranes hybridized with sense probe were devoid of signal.

In situ hybridization. Coronal tissue sections through the forebrain were cut using a cryostat ( $14 \mu \mathrm{m}$ thickness for the developmental studies, $10 \mu \mathrm{m}$ thickness for the adult rat kainate treatment experiments) and stored at $-20^{\circ} \mathrm{C}$. The slide-mounted sections were processed for the localization of HB-EGF mRNA by in situ hybridization as described previously (Seroogy et al., 1993, 1994, 1995; Seroogy and Herman, 1997). The antisense HB-EGF cRNA was transcribed in vitro from a pBluescript vector containing a $258 \mathrm{bp}$ fragment from the $5^{\prime}$ end of the cloned rat cDNA using T3 RNA polymerase in the presence of $\left.{ }^{35} \mathrm{~S}\right] \mathrm{UTP}$. Hybridization was accomplished at $60^{\circ} \mathrm{C}$ for $18-20 \mathrm{hr}$ in a solution containing the $\left.{ }^{35} \mathrm{~S}\right]$-labeled HB-EGF cRNA probe at a concentration of $1 \times 10^{6}$ $\mathrm{cpm} / 0.50 \mathrm{ml}$ per slide. After post-hybridization ribonuclease treatment and washes in SSC, the distribution of hybridization was localized by film [( $\beta$-Max Hyperfilm; Amersham, Arlington Heights, IL) $10 \mathrm{~d}$ exposures for the experimental/seizure series, $14 \mathrm{~d}$ exposures for the developmental series] and then emulsion [(Kodak NTB2) 4 week exposures for the experimental/seizure series, 6 week exposures for the developmental series] autoradiography. The differences in exposure times were chosen, on the one hand, to accentuate the normal developmental distribution of HB-EGF mRNA, and, on the other hand, to emphasize the effect between control and experimental/seizure-induced expression without overexposing the film at certain time points. Control sections were pretreated with ribonuclease $\mathrm{A}\left(45^{\circ} \mathrm{C}\right.$ for $\left.30 \mathrm{~min}\right)$ before hybridization with the antisense probe or were hybridized with the $\left[{ }^{35} \mathrm{~S}\right]$-labeled sense sequence (transcribed using T7 polymerase). No specific labeling was observed in tissue processed under either control condition.

Western blot analysis. These methods were similar to those described in our previous studies (Cheng et al., 1995). Hippocampal homogenates were prepared as detailed elsewhere (Cheng et al., 1995) and assayed for protein content at $562 \mathrm{~nm}$ using a BCA kit (Pierce, Rockford, IL) according to the manufacturer's protocol. Proteins were separated by SDS-PAGE in $15 \%$ gel and then transferred electrophoretically to Hybond Membrane (Bio-Rad, Hercules, CA). The membranes were blocked in TBS containing $5.0 \%$ nonfat milk and $0.1 \%$ Tween-20, and then incubated overnight at $4^{\circ} \mathrm{C}$ in PBS containing primary antibody (goat polyclonal anti-HB-EGF antibody 197; provided by Judith Abraham, Scios Inc.) The membranes were then incubated for $1 \mathrm{hr}$ at room temperature in TBS containing a peroxidase-conjugated rabbit anti-goat secondary antibody (Jackson ImmunoResearch Laboratories, West Grove, PA) and processed further using a chemiluminescence detection system (ECL system; Amersham). Human recombinant HB-EGF (R\&D Systems, Minneapolis, MN) and lung tissue were used as positive controls for the HB-EGF antibody, and BSA was used as a negative control. To verify equal protein gel loading, membranes were stripped and reprobed with an anti-neurofilament $(200 \mathrm{kDa})$ protein antibody $(1: 500$ dilution; Sternberger Monoclonals, Lutherville, MD). Equivalent electrophoretic transfer of protein was verified on membranes reversibly stained with Ponceau S dye.

Hippocampal cell cultures and quantification of neuronal survival. Primary hippocampal cell cultures were established from embryonic rats (day 18 of gestation) as detailed elsewhere (Mattson et al., 1995). Cultures were maintained in Eagle's Minimum Essential Medium supplemented with $10 \%(\mathrm{v} / \mathrm{v})$ heat-inactivated fetal bovine serum (Life Technologies), $20 \mathrm{~mm} \mathrm{KCl}$, and $1 \mathrm{~mm}$ pyruvate. Experiments were performed in cultures that had been maintained for $6-10 \mathrm{~d}$. In these cultures, $90 \%$ of the cells are neurons, and the remaining cells are astrocytes, as judged by characteristic morphology and differential immunoreactivity with antibodies to neuron-specific (neurofilament, MAP2, and tau) and astrocyte-specific (glial fibrillary acidic protein and S-100 $\beta$ ) proteins (Mattson et al., 1993, 1995). Immediately before experimental treatment, the culture maintenance medium was replaced with Locke's solution containing (in mM): $\mathrm{NaCl} 154, \mathrm{KCl} 5.6, \mathrm{CaCl}_{2} 2.3, \mathrm{MgCl}_{2} 1.0, \mathrm{NaHCO}_{3}$ 3.6, glucose 10, and HEPES buffer 5, $\mathrm{pH}$ 7.2. Cultures were pretreated for $16 \mathrm{hr}$ with HB-EGF in Locke's solution before the addition of kainate 
(Sigma). Neuronal survival was quantified by counting the number of viable neurons in premarked microscope fields before and at indicated time points after exposure to experimental treatments as described previously (Mattson et al., 1995).

Measurement of intracellular calcium levels. The intracellular free calcium concentration $\left(\left[\mathrm{Ca}^{2+}\right]_{\mathrm{i}}\right)$ in individual neuronal cell bodies was quantified by ratiometric imaging of the calcium indicator dye fura- 2 acetoxymethyl ester as described previously (Mark et al., 1995; Mattson et al., 1995). Cells were pretreated for $16 \mathrm{hr}$ with $100 \mathrm{ng} / \mathrm{ml} \mathrm{HB-EGF} \mathrm{or}$ vehicle and then incubated at $37^{\circ} \mathrm{C}$ with fura- 2 for $30 \mathrm{~min}$. After rinsing, cultures were placed in HBSS supplemented with $10 \mathrm{~mm}$ glucose and 10 mM HEPES, pH 7.2. Cells were imaged using a Zeiss Attofluor system, which included a Zeiss Axiovert microscope with a $40 \times$ oil objective and an Attofluor-intensified CCD camera. The dye was excited at 340 and 380 $\mathrm{nm}$, and images were taken of the emitted fluorescence after excitation at each wavelength. The method of Grynkiewicz et al. (1985) was used to calibrate the system and quantify $\left(\left[\mathrm{Ca}^{2+}\right]_{i}\right)$. The $\left[\mathrm{Ca}^{2+}\right]_{\mathrm{i}}$ in individual neuronal cell bodies was monitored at $7 \mathrm{sec}$ intervals for $1 \mathrm{~min}$ before, and 5 min after, exposure to kainate. Values for peak $\left[\mathrm{Ca}^{2+}\right]_{\mathrm{i}}$ were determined and used for statistical comparisons between control cultures and those pretreated with HB-EGF.

\section{RESULTS}

\section{Postnatal ontogeny of HB-EGF mRNA expression in rat hippocampus and forebrain}

As determined by in situ hybridization, expression of HB-EGF mRNA was evident in hippocampal neurons at all ages examined (Fig. 1). From P0 to P7, labeling was distributed within all principle cell layers of the hippocampus, including stratum pyramidale fields CA1-CA3 and stratum granulosum of the dentate gyrus. However, by P14 and through adulthood, hybridization decreased substantially in the pyramidal cell layer to levels just slightly above background. In contrast, levels of HB-EGF mRNA appeared to slightly increase in stratum granulosum throughout development (Fig. 1). During development and in the adult, labeled cells were never detected in the molecular layers of the hippocampus or in the hilus of the dentate gyrus. In neocortex, hybridization for HB-EGF mRNA was localized to cell bodies in middle layers, with levels being greatest at P7 and then declining through adulthood (Fig. 1). The pattern of neocortical labeling appears to correspond to the region of somatosensory cortex. HB-EGF mRNA was also moderately expressed neonatally in other cortical areas, including entorhinal, piriform, and retrosplenial cortices; hybridization levels decreased with increasing age in these regions (data not shown). Moderate labeling for HB-EGF mRNA was also present neonatally in the taenia tecta and within several thalamic regions, including the dorsolateral and medial geniculate nuclei and the ventrobasal complex (data not shown). Again, hybridization levels in these latter regions declined substantially throughout postnatal development to very low to undectectable levels in the adult. Labeling for HB-EGF mRNA was never localized to regions of white matter in the forebrain (i.e., corpus callosum, anterior commissure, internal and external capsules, lateral olfactory tract, optic tract, etc.) at any of the ages examined.

\section{HB-EGF mRNA expression in hippocampus after kainate administration}

To determine whether HB-EGF mRNA is modulated by neuronal activity/injury, kainate was administered to adult rats (12 $\mathrm{mg} / \mathrm{kg}$, i.p.) to induce seizures, and rats were killed 3, 6, 12, 24 and $48 \mathrm{hr}$ later. We first assessed overall levels of HB-EGF mRNA in hippocampus by Northern blot analysis (Fig. 2). An increase in the $2.5 \mathrm{~kb}$ HB-EGF transcript was detected $3 \mathrm{hr}$ after kainate administration, and the level of HB-EGF mRNA continued to increase through 6 and $12 \mathrm{hr}$, with peak expression occur-
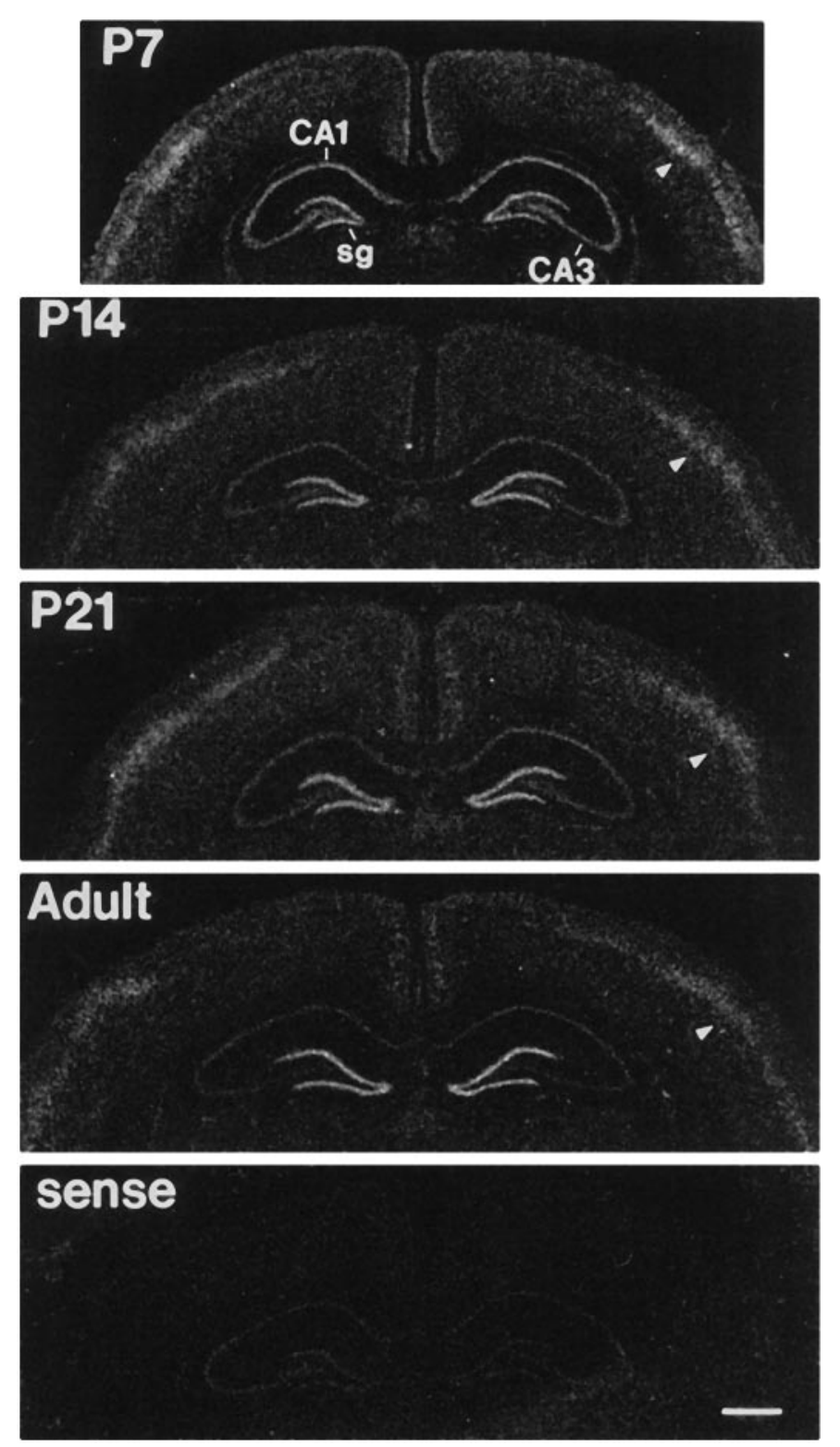

Figure 1. Expression of HB-EGF mRNA in developing hippocampus. Autoradiograms showing the in situ hybridization localization of HBEGF mRNA in coronal sections through the hippocampus at the indicated postnatal day ages. Note that at $P 7$, labeling is present throughout hippocampal fields $C A 1$ and $C A 3$ and dentate gyrus stratum granulosum $(s g)$, whereas in older (P14, P21, Adult) rats, HB-EGF mRNA expression is substantially reduced in the pyramidal cell layer relative to the stratum granulosum. In neocortex, HB-EGF cRNA hybridization is prominent in the middle layers (arrowheads), with levels gradually declining from P7 to adulthood. The bottom panel (sense) demonstrates the lack of hybridization obtained with the control sense cRNA probe in a section through the adult hippocampus. Film exposure, $14 \mathrm{~d}$; section thickness, $14 \mu \mathrm{m}$. Scale bar, $1000 \mu \mathrm{m}$.

ring at the $24 \mathrm{hr}$ time point. HB-EGF mRNA levels were declining toward control levels at $48 \mathrm{hr}$ after kainate administration (Fig. 2).

In situ hybridization analyses demonstrated an extensive increase in HB-EGF mRNA within the hippocampus, as well as in other limbic and cortical structures, after kainate treatment (Fig. 3; see summary in Table 1). In the hippocampus, there was a pronounced increase in HB-EGF cRNA hybridization in the 
A

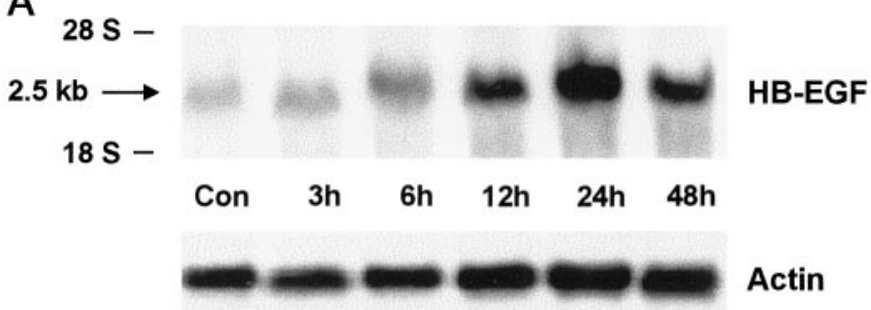

B

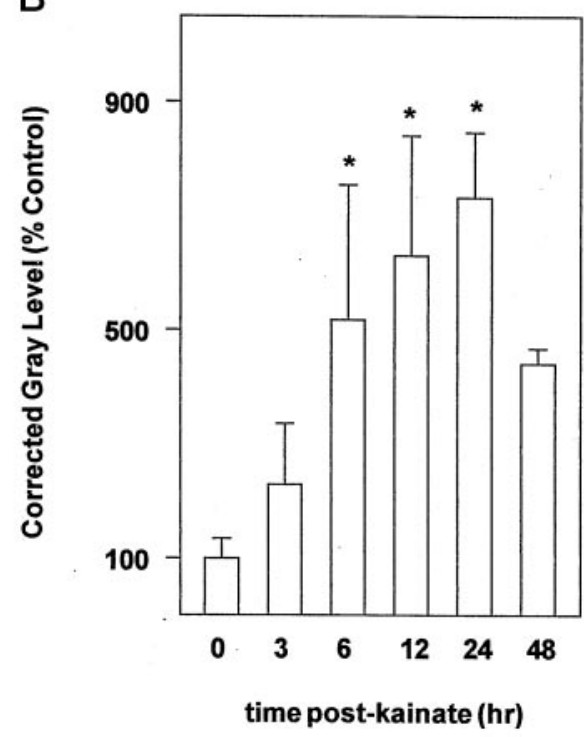

Figure 2. A, Northern blot analysis of HB-EGF mRNA levels in adult rat hippocampus at various survival times (3-48 hr) after kainate administration. Total RNA $(20 \mu \mathrm{g} /$ lane $)$ was separated on a $1.2 \%$ agarose gel, transferred to nylon membrane, and hybridized with an antisense ${ }^{32} \mathrm{P}$ cRNA HB-EGF probe (top). Membranes were stripped and reprobed with a ${ }^{32} \mathrm{P}$-labeled $\beta$ actin cRNA to control for equal loading of RNA (bottom). HB-EGF mRNA was detected by autoradiography with an exposure time of $5 \mathrm{~d}$. Levels of the $2.5 \mathrm{~kb}$ transcript corresponding to HB-EGF mRNA were elevated $3 \mathrm{hr}$ after kainate treatment and continued to increase through the $24 \mathrm{hr}$ time point. By $48 \mathrm{hr}$, HB-EGF mRNA levels were declining. Con, Control. B, Densitometric analysis of HB-EGF mRNA levels at various times after kainate administration. HB-EGF mRNA levels were normalized relative to $\beta$ actin mRNA levels. Data are expressed as mean \pm SEM of determinations made in three rats per time point and were analyzed by one-way ANOVA with Duncan post hoc analysis. ${ }^{*} p<0.05$ compared with the control $(0 \mathrm{hr})$ value.

stratum granulosum of the dentate gyrus that was evident at $3 \mathrm{hr}$, reached maximal levels at $6 \mathrm{hr}$, and declined to control levels by $48 \mathrm{hr}$ after kainate administration (Figs. 3, 4). By the $6 \mathrm{hr}$ time point, increased expression was no longer restricted to the dentate granule cells such that labeled perikarya were now scattered in the hilus and molecular layer of the dentate gyrus (Fig. 4C). The densely labeled cells were most numerous in these regions between 12 and $24 \mathrm{hr}$ after kainate treatment (Figs. 3D, E, 4D); by $48 \mathrm{hr}$, HB-EGF cRNA-hybridizing cells were no longer detected in the dentate hilus and molecular layer (Fig. $4 E$ ), as in control brains.

Between 12 and $24 \mathrm{hr}$ after kainate administration, HB-EGF cRNA hybridization was prominently elevated in perikarya within and around stratum pyramidale of the hippocampus (Fig. $3 D, E)$. In and adjacent to region CA3, labeling was highest at 12 hr and declined to control levels by $48 \mathrm{hr}$. Cells expressing HB-EGF mRNA were observed within region CA1 and were scattered in the molecular layers surrounding CA1 (strata oriens and radiatum) by $12 \mathrm{hr}$ after kainate administration (Figs. 3D, $5 C$ ). However, at later survival periods, the labeled cells were located in successively closer proximity to the pyramidal cell layer of CA1 (Fig. 5D) such that by $48 \mathrm{hr}$, expression was restricted to cells dispersed within or along the edge of the CA1 cell layer (Figs. $3 F, 5 E$ ).

\section{HB-EGF mRNA expression in extra-hippocampal regions after kainate administration}

Injection of kainate induced the expression of HB-EGF mRNA in several forebrain limbic and cortical regions outside of the hippocampus (Table 1). In the neocortex, hybridization signal was elevated in middle layers within $3 \mathrm{hr}$ of kainate administration (Figs. $3 B, 6 B$ ) and peaked between 12 and $24 \mathrm{hr}$, at which time HB-EGF cRNA-hybridizing cells appeared to encompass nearly all cortical laminae (Figs. 3D,E, 6C,D). However, by the $48 \mathrm{hr}$ time point, labeled cells were again absent from the neocortex (Figs. $3 F, 6 E$ ). Kainate treatment increased HB-EGF mRNA levels in piriform cortex within $3 \mathrm{hr}$ of administration (Fig. 6), with highest levels of expression observed at the 12 and $24 \mathrm{hr}$ time points (Fig. 6). In addition to the piriform cortex, transient elevations in HB-EGF mRNA expression were found in other olfactory-related areas, including the entorhinal cortex, amygdaloid nuclei, olfactory tubercle, and anterior olfactory nuclei after kainate treatment (Table 1). Kainate administration also induced dense hybridization for HB-EGF mRNA in numerous perikarya of the lateral septal nuclei, with peak expression found between 12 and $24 \mathrm{hr}$ after injection (Fig. 6). Transient increases in HB-EGF cRNA hybridization were also noted in several thalamic and hypothalamic nuclei (Table 1). Finally, mainly at the 24 and $48 \mathrm{hr}$ time points, perikarya densely labeled for HB-EGF mRNA surrounded prescribed areas of the perirhinal, piriform, and entorhinal cortices and amygdala, as well as several thalamic regions (Figs. 3, 6; Table 1).

\section{Relationships between kainate-induced neuronal degeneration and HB-EGF mRNA localization}

Systemic administration of kainate results in a characteristic pattern of neuronal cell loss, which in the hippocampus involves regions CA1 and CA3 strata pyramidale, as well as hilar neurons (Nadler et al., 1978; Sperk et al., 1983; Ben-Ari, 1985). As expected, this pattern of cell loss was observed in the present study. At the $48 \mathrm{hr}$ survival time, HB-EGF mRNA-labeled cells were consistently present in the proximity of vulnerable regions of hippocampus (Figs. 3, 5). In addition, degenerating regions of amygdala, piriform cortex, and related areas of cortex and thalamus were encircled by HB-EGF cRNA-hybridizing cells 24-48 hr after kainate administration (Figs. 3, 6, 7). An example of this hybridization pattern can be seen in Figure 7 where HB-EGF mRNA-expressing perikarya are lining the medial edge of the amygdala, a structure that has undergone extensive cell loss $48 \mathrm{hr}$ after kainate treatment.

\section{HB-EGF protein expression in hippocampus after kainate administration}

Western blot analysis was used to examine alterations in HB-EGF protein levels in hippocampus at various survival times after kainate treatment. Consistent with previous studies (Ono et al., 1994; Kim et al., 1995; Davis et al., 1996), HB-EGF protein was identified as four species, with apparent molecular weights ranging from 14 to $27 \mathrm{kDa}$ (Fig. 8); none of the four bands were present when the primary antibody was preincubated with excess 
Table 1. Relative hybridization densities ${ }^{a}$ of HB-EGF mRNA in rat forebrain after kainate-induced seizures

\begin{tabular}{|c|c|c|c|c|c|c|}
\hline \multirow[b]{2}{*}{ Brain region } & \multicolumn{6}{|c|}{ Time after kainate injection } \\
\hline & 0 & $3 \mathrm{hr}$ & $6 \mathrm{hr}$ & $12 \mathrm{hr}$ & $24 \mathrm{hr}$ & $48 \mathrm{hr}$ \\
\hline Frontal cortex & - & + & + & ++ & ++ & - \\
\hline Cingulate cortex & - & + & + & ++ & $+/-$ & - \\
\hline Entorhinal cortex* & $+1-$ & + & + & + & ++ & ++ \\
\hline Perirhinal cortex* & $+/-$ & + & + & ++ & ++ & ++ \\
\hline Piriform cortex* & + & + & ++ & +++ & +++ & ++ \\
\hline Olfactory tubercle & $+/-$ & + & ++ & ++ & ++ & $+/-$ \\
\hline Anterior olfactory nuclei & - & + & + & + & ++ & $+/-$ \\
\hline Caudate-putamen & - & - & - & $+1-$ & $+/-$ & - \\
\hline Lateral septal nucleus & - & + & ++ & +++ & ++++ & + \\
\hline Amygdaloid complex* & - & $+/-$ & + & + & ++ & ++ \\
\hline Dentate gyrus GCL & ++ & ++++ & ++++ & +++ & ++ & ++ \\
\hline Hippocampal CA1 region* & $+1-$ & $+/-$ & + & ++++ & ++++ & ++ \\
\hline Hippocampal CA3 region* & $+/-$ & $+/-$ & + & +++ & ++ & $+1-$ \\
\hline Medial thalamic nuclei* & - & - & + & ++ & + & ++ \\
\hline VPM & $+/-$ & + & + & ++ & ++ & $+/-$ \\
\hline VPL & $+/-$ & + & + & ++ & ++ & $+/-$ \\
\hline Medial geniculate nucleus & $+/-$ & + & + & ++ & ++ & $+1-$ \\
\hline Anterior hypothalamic nucleus & - & - & ++ & ++ & + & - \\
\hline VM hypothalamic nucleus & - & - & ++ & ++ & + & - \\
\hline
\end{tabular}

GCL, Granule cell layer; VM, hypothalamic nucleus, ventromedial hypothalamic nucleus; VPL, ventroposterolateral thalamic nucleus; VPM, ventroposteromedial thalamic nucleus.

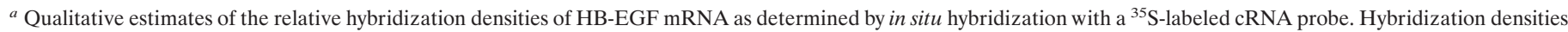

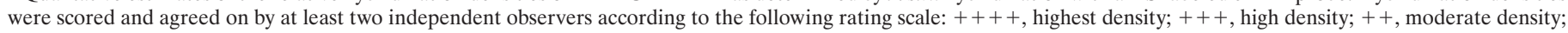

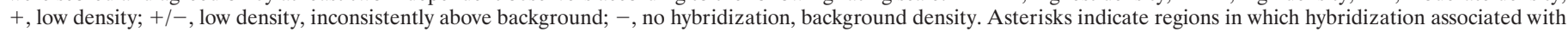
cells surrounding fields of neural degeneration persisted at the 24 and $48 \mathrm{hr}$ post-kainate time points, as discussed in Results.

(50 ng) recombinant human HB-EGF (data not shown). Levels of the 14 and $27 \mathrm{kDa}$ isoforms increased after $3 \mathrm{hr}$ and peaked at 24 hr after kainate treatment. Levels of HB-EGF protein declined but were still above control levels $48 \mathrm{hr}$ after kainate administration (Fig. 8). By $72 \mathrm{hr}$ after kainate treatment, expression of the $14 \mathrm{kDa}$ HB-EGF isoform remained elevated.

\section{HB-EGF protects hippocampal neurons against kainate toxicity}

Exposure of cultures to kainate (10-50 $\mu \mathrm{M}$ for $12 \mathrm{hr}$ ) resulted in concentration-dependent decreases in neuronal survival (Fig. 9). Approximately 40 and $85 \%$ of rat hippocampal neurons degenerated after exposure to 10 and $50 \mu \mathrm{M}$ kainate, respectively. Neuronal survival was increased in a concentration-dependent manner after pretreatment with HB-EGF. When cultures were pretreated with HB-EGF (10-100 ng/ml) for $16 \mathrm{hr}$, there was a dramatic reduction in kainate-induced neuronal damage when compared with cultures not receiving growth factor. Shorter pretreatments with HB-EGF (2-6 hr exposures to $100 \mathrm{ng} / \mathrm{ml}$ HB-EGF) did not protect neurons against kainate toxicity (data not shown). The protection against kainate toxicity afforded by HB-EGF was sustained for at least $48 \mathrm{hr}$ (Fig. 9B), indicating that HB-EGF prevented neuronal death rather than just delaying the death. Calcium influx has previously been shown to play an important role in neuronal injury induced by kainate (Choi, 1987; Giusti et al., 1995). To determine whether HB-EGF protects against neurotoxicity by suppressing the kainate-induced rise in $\left[\mathrm{Ca}^{2+}\right]_{\mathrm{i}}$, calcium levels were measured in cultured hippocampal neurons by ratiometric imaging of the fluorescent calcium indicator dye fura-2. Cultures were pretreated with $100 \mathrm{ng} / \mathrm{ml} \mathrm{HB}$ EGF for $16 \mathrm{hr}$ and then challenged with $50 \mu \mathrm{M}$ kainate for $5 \mathrm{~min}$. After exposure to kainate the $\left[\mathrm{Ca}^{2+}\right]_{\mathrm{i}}$ in neurons was increased to $\sim 350 \mathrm{~nm}$ compared with $100 \mathrm{~nm}\left[\mathrm{Ca}^{2+}\right]_{\mathrm{i}}$ in neurons exposed to vehicle (Fig. 10). The elevation in $\left[\mathrm{Ca}^{2+}\right]_{i}$ in response to kainate was not attenuated by pretreatment with HB-EGF.

\section{DISCUSSION}

The principal findings of the present study reveal that HB-EGF mRNA and protein are dramatically upregulated in the hippocampal formation after seizure-induced neuronal activity/injury. Sustained HB-EGF expression was also induced in forebrain areas vulnerable to degeneration after seizures. Moreover, our in vitro data indicate that HB-EGF is neuroprotective for hippocampal neurons against kainate toxicity, with an excitoprotective mechanism different from that of previously characterized excitoprotective trophic factors. Taken together, these results provide the first evidence that a member of the EGF family may play a role in neuroprotection and in the longer-term neuropathological changes associated with seizures.

The regional and temporal patterns of HB-EGF mRNA expression in response to kainate-induced seizures exhibited features similar to those described previously for other neurotrophic factors. Accordingly, HB-EGF mRNA was robustly expressed in several limbic, cortical, and subcortical regions after kainate administration. The earliest alterations in HB-EGF mRNA levels occurred in hippocampus, followed by a more gradual and widespread induction in cortical and septal areas. In hippocampus, HB-EGF mRNA was rapidly induced in neurons of the dentate gyrus granule cell layer followed by a more protracted upregulation in the CA1-CA3 regions and molecular layers. The alterations in hippocampal HB-EGF mRNA were accompanied by a corresponding elevation in HB-EGF protein; both mRNA and protein levels appeared to peak between 12 and $24 \mathrm{hr}$ after 



Figure 3. Kainate-induced increase of HB-EGF mRNA expression in hippocampus. Autoradiograms demonstrating the in situ hybridization localization of HB-EGF mRNA in coronal sections through the hippocampus in a saline-injected control rat $(A)$ and in rats killed $3(B), 6(C), 12(D), 24(E)$, and $48 \mathrm{hr}(F)$ after kainate administration. Expression of HB-EGF mRNA is upregulated in the granule cell layer [stratum granulosum $(s g)$ ] of the dentate gyrus 3-6 hr after kainate treatment $(B, C)$ but then declines to control levels by $48 \mathrm{hr}(F)$. Kainate treatment induces prominent hybridization in and around the pyramidal cell layers of hippocampal subfields $C A 1$ and $C A 3$ at the 12 and $24 \mathrm{hr}$ time points $(D, E)$; by 48 hr, labeling is restricted to the CA1 region in the hippocampus $(F)$. In neocortex $(n c)$, HB-EGF mRNA expression increases from 3 to 12 hr after kainate treatment ( $B-D$ ) and then decreases to control levels by $48 \mathrm{hr}(E, F)$. Note that hybridization signal is also present in and around areas of kainate-induced cell loss at the 24 and $48 \mathrm{hr}$ time points $(E, F)$, including regions of the dorsal lateral thalamus (arrows in $F$ ), amygdaloid complex (amg), and piriform cortex ( $p c$ ). Film exposure, $10 \mathrm{~d}$; section thickness, $10 \mu \mathrm{m}$. Note that because of thinner sectioning and shorter exposure time, the control section in $A$ cannot be directly compared with the normal adult section in Figure 1. Scale bar, $1000 \mu \mathrm{m}$. 

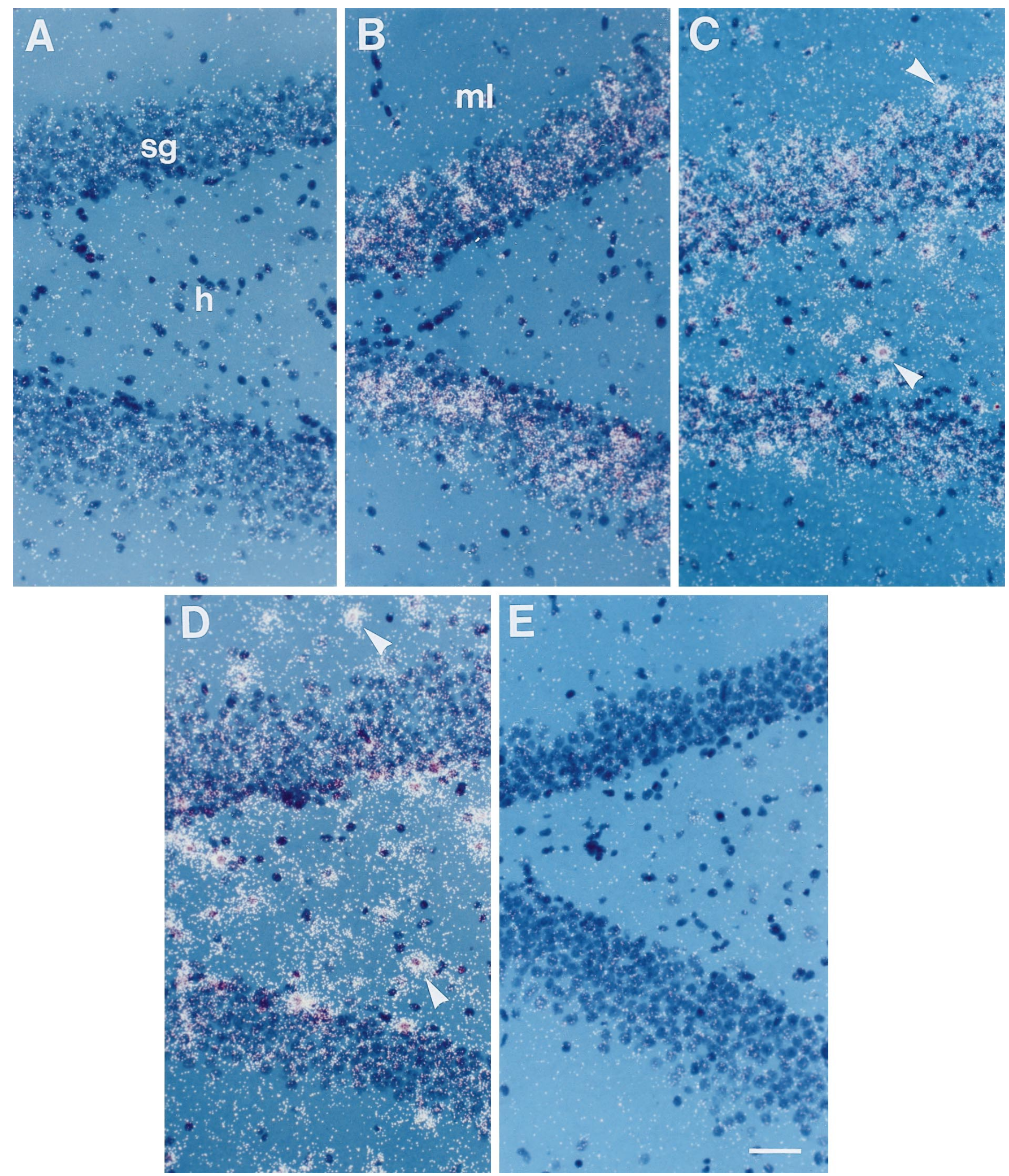

Figure 4. Kainate-induced increase of HB-EGF mRNA in dentate gyrus. Dark-field photomicrographs showing the cellular distribution of HB-EGF mRNA in sections through the dentate gyrus in a saline-injected control rat $(A)$ and in rats killed $3(B), 6(C), 24(D)$, and $48 \mathrm{hr}(E)$ after kainate administration. Note that kainate treatment initially increased HB-EGF cRNA hybridization in the granule cell layer [stratum granulosum $(s g)$ ] at the $3 \mathrm{hr}$ time point $(B)$. However, from 6 to $24 \mathrm{hr}$ after kainate injection, numerous labeled cells (arrowheads indicate several examples) were distributed throughout the hilus $(h)$ and molecular layer $(m l)(C, D)$. By $48 \mathrm{hr}$, cellular expression of HB-EGF mRNA was barely detectable within the dentate gyrus (E). Scale bar, $50 \mu \mathrm{m}$. 

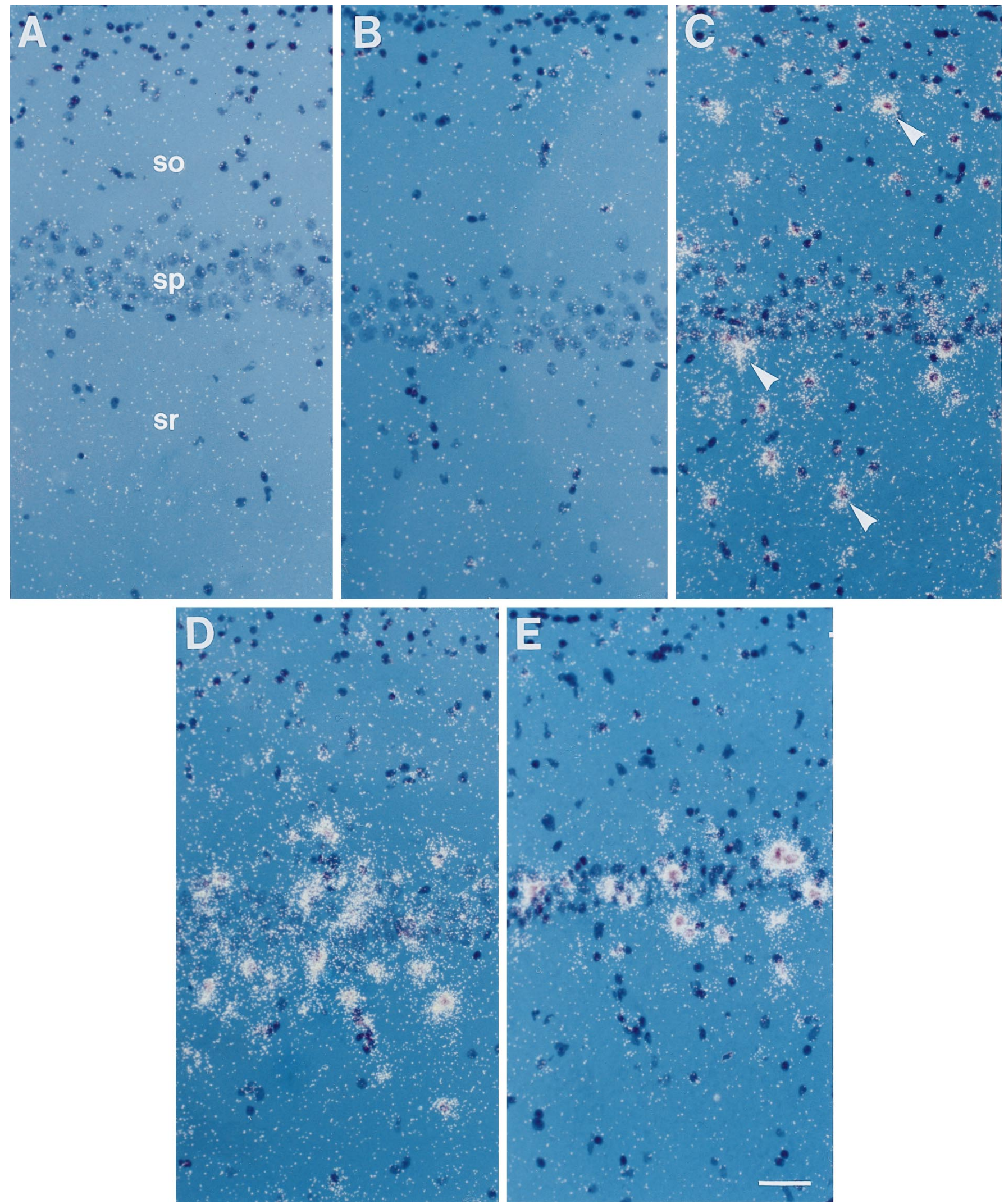

Figure 5. Kainate-induced increase of HB-EGF mRNA in hippocampal region CA1. Dark-field photomicrographs show the autoradiographic localization of HB-EGF cRNA in situ hybridization in the CA1 region of hippocampus in a saline-injected control rat $(A)$ and in rats killed $3(B), 12(C), 24(D)$, and $48 \mathrm{hr}(E)$ after kainate administration. Note that by $12 \mathrm{hr}$ after kainate injection, labeling for HB-EGF mRNA was induced in stratum pyramidale $(s p)$ and particularly within numerous cells scattered throughout the stratum oriens $(s o)$ and stratum radiatum (sr) molecular layers $(C$, arrowheads indicate examples of labeled somata). By $24 \mathrm{hr}$, densely labeled cells were situated in close proximity to the pyramidal cell layer $(D)$. At $48 \mathrm{hr}$ after kainate treatment, perikarya expressing HB-EGF mRNA were intermittently dispersed within and along the edges of CA1 stratum pyramidale $(E)$. Scale bar, $50 \mu \mathrm{m}$. 

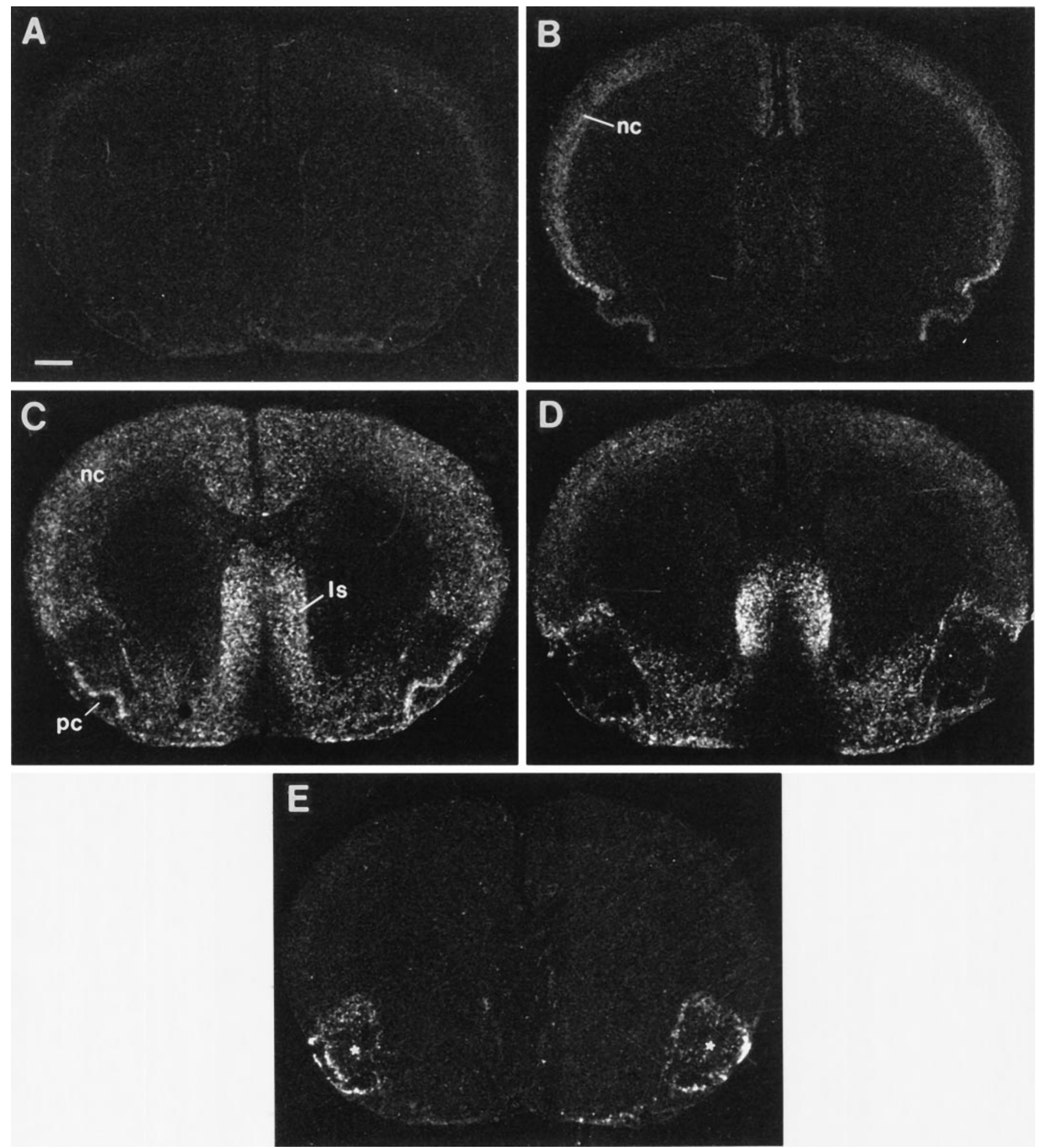

Figure 6. Kainate-induced expression of HB-EGF mRNA in septum and cortex. Autoradiograms demonstrating the regional distribution of HB-EGF cRNA hybridization in coronal sections through the septal nuclei in a saline-injected control rat $(A)$ and in rats killed at $3(B), 12(C), 24(D)$, and 48 $\mathrm{hr}(E)$ after kainate administration. Expression of HB-EGF mRNA is induced in the lateral septal nuclei $(l s)$, neocortex $(n c)$, and piriform cortex $(p c)$ by $3 \mathrm{hr}$ after kainate treatment $(B)$, with peak expression levels found between 12 and $24 \mathrm{hr}$ after kainate treatment $(C, D)$. By $48 \mathrm{hr}(E)$, labeling is restricted to scattered cells within the lateral septum and piriform cortex and to degenerating areas of perirhinal cortex (asterisks). Film exposure, $10 \mathrm{~d}$; section thickness, $10 \mu \mathrm{m}$. Scale bar, $1000 \mu \mathrm{m}$. 


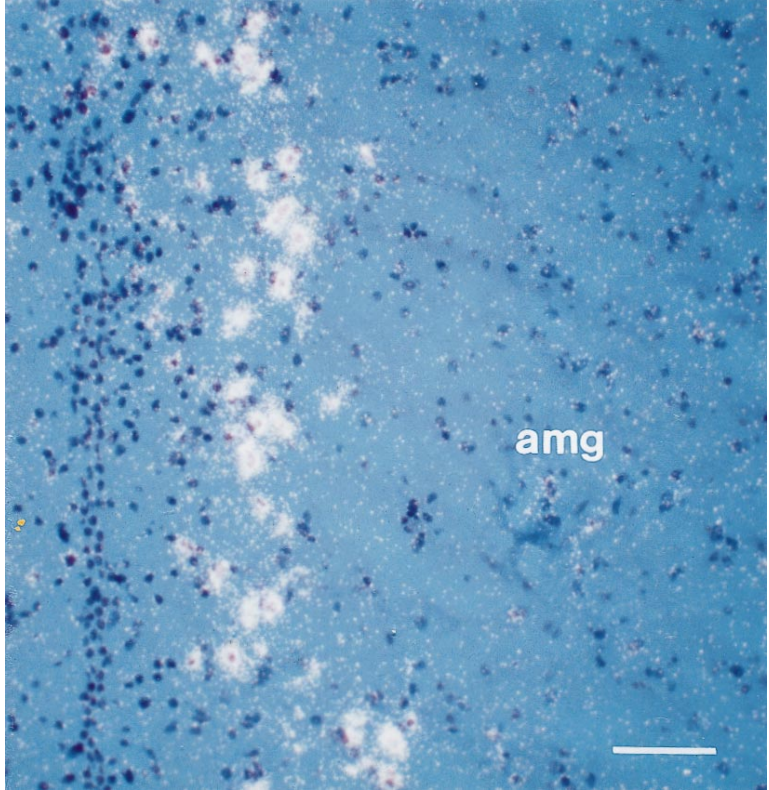

Figure 7. Kainate-induced expression of HB-EGF mRNA in extrahippocampal regions of neuronal cell loss. Dark-field photomicrograph shows HB-EGF cRNA-hybridizing cells lining the medial edge of the amygdaloid complex (amg) in a rat killed $48 \mathrm{hr}$ after kainate administration. Scale bar, $90 \mu \mathrm{m}$.

kainate injection. These findings demonstrate that HB-EGF expression is highly responsive to neuronal activity/injury consistent with roles in neuronal plasticity and injury responses.

The HB-EGF mRNA expression that occurred $24-48 \mathrm{hr}$ after kainate injection in regions of neuronal degeneration (CA1 region of hippocampus, amygdala, piriform and entorhinal cortices) may represent expression by reactive astrocytes, activated microglia, or infiltrating macrophages. Indeed, HB-EGF was originally identified as a macrophage-derived secretory product (Higashiyama et al., 1991). The appearance of reactive astrocytes and infiltration of microglia has previously been connected with kainic acid-induced neuronal damage (Sperk et al., 1983; Marty et al., 1991; Sperk, 1994). Although microglia may participate in inflammatory responses and can phagocytose damaged cells, increasing data suggest that microglia also produce neurotrophic substances. For example, activated microglia produce both bFGF and TNF $\alpha$, both of which have been shown to protect neurons against various insults (Mattson et al., 1989; Cheng and Mattson, 1991; Cheng et al., 1994). Furthermore, it was recently reported that microglia express TGF- $\beta 1$ in the hippocampus, particularly in areas undergoing neurodegeneration after a systemic kainate injection (Morgan et al., 1993). These findings led to the hypothesis that recruitment of microglia and secretion of trophic factors may be important for early repair processes after neuronal injury. Similarly, HB-EGF induction after kainate-induced seizures may be indicative, in part, of activated microglia or astrocytes that respond to chemotactic factors released by dying neurons. In this view, the upregulation of $\mathrm{HB}-\mathrm{EGF}$ is an adaptive response to neuronal activation and/or damage because induction continues during the period of neuronal degeneration.

The spatial and temporal increases in HB-EGF mRNA levels raise interesting questions regarding mechanisms of both gene and protein regulation. Modulation of HB-EGF mRNA expression was most likely stimulated by seizure-induced neuronal activity and/or cell death elicited by the kainate treatment, because rats that did not exhibit overt convulsive behavior failed to show elevated levels of HB-EGF mRNA or protein (L. A. Opanashuk and K. B. Seroogy, unpublished data). Regulation of some neurotrophic factors, for example BDNF, has previously been tightly linked to an appropriate balance between activation of GABA and glutamate receptors (Zafra et al., 1991). The varying kinetics of regional HB-EGF expression are suggestive of differential mechanisms of gene regulation. In some situations, HB-EGF has been designated as an immediate early gene (Polihronas et al., 1996) and might therefore serve functions similar to BDNF (Hughes et al., 1993; Lauterborn et al., 1996). This may be the case in the dentate gyrus granule cells because increases in HB-EGF protein were evident within $3 \mathrm{hr}$ of kainate administration, a time period too short to permit de novo protein synthesis to take place before upregulation of the HB-EGF gene. Furthermore, levels of both the transmembrane and secreted forms of HB-EGF protein were moderately elevated $3 \mathrm{hr}$ after treatment, suggesting that both transcriptional and post-translational mechanisms may be important in the processing of HB-EGF protein in the hippocampus. Alternative mechanisms may be responsible for the more protracted increases in HB-EGF mRNA. For example, other trophic molecules, peptides, or cytokines may mediate the induction of HB-EGF mRNA. In support of the latter possibility, HB-EGF gene expression was previously shown to be autoregulated (Barnard et al., 1994) and was also upregulated in response to $\mathrm{TNF} \alpha$, thrombin, and TGF $\alpha$ (Yoshizumi et al., 1992; Tan et al., 1994; Dlugosz et al., 1995). Regardless of the mechanisms involved, it still remains to be determined whether increases in
Figure 8. Western blot analysis of HBEGF protein in rat hippocampus (top panel), in a saline-injected control rat (Con), and in rats killed at the indicated time points after kainate administration. Protein $(100 \mu \mathrm{g} /$ lane $)$ was separated by SDS-PAGE, transferred to Hybond (Amersham) membrane, and probed with a polyclonal antibody to HB-EGF (kindly provided by Judith Abraham, Scios Inc.). Proteins were visualized by enhanced chemiluminescence. Recombinant human HB-EGF (10 ng) was used as a positive control. Four bands corresponding to HB-EGF with apparent molecular weights of $27,24,17$, and $14 \mathrm{kDa}$ are detected in hippocampal extracts.

Similar results were obtained in three different rats for each time point. Membranes were also probed with a monoclonal antibody for neurofilament protein (bottom panel) to ensure equivalent gel loading.
$\mathrm{kDa}$
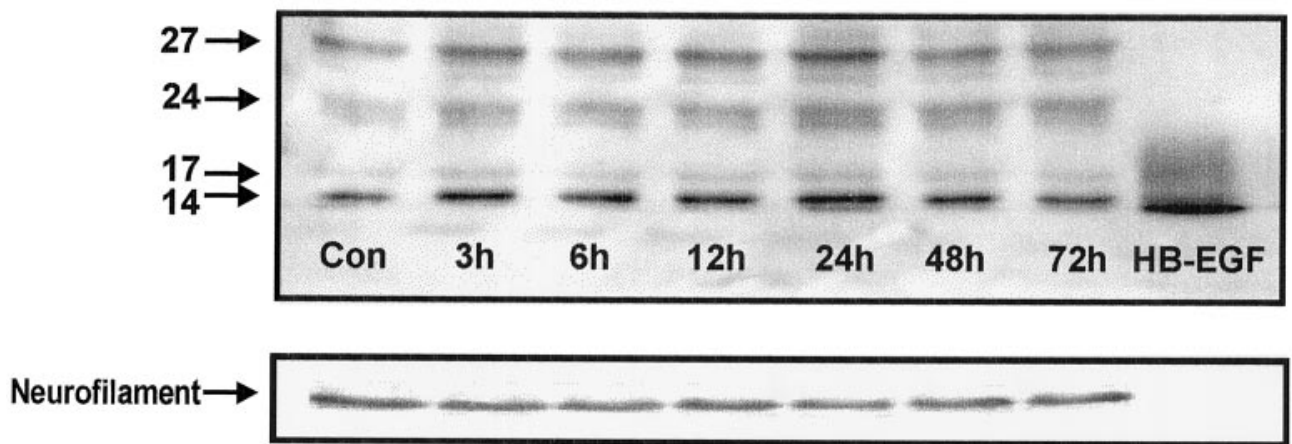

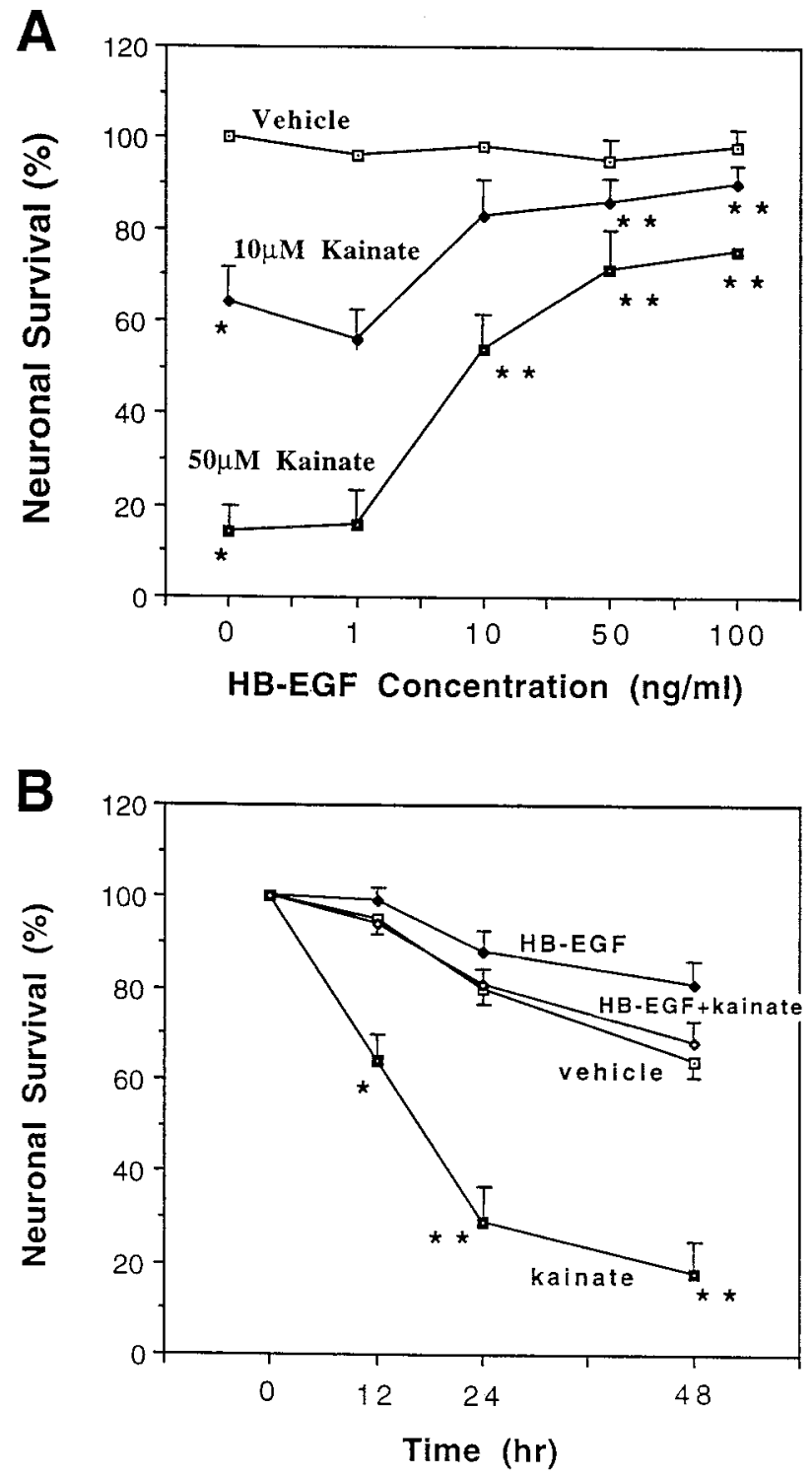

Figure 9. HB-EGF protects against kainate neurotoxicity in hippocampal cell cultures. $A$, Cultures were pretreated with $1-100 \mathrm{ng} / \mathrm{ml}$ human recombinant HB-EGF for $16 \mathrm{hr}$ and were then exposed to either 10 or 50 $\mu \mathrm{M}$ kainate. Neuronal survival was assessed $12 \mathrm{hr}$ after kainate treatment. Values represent the mean \pm SEM of determinations made in five separate experiments. Pair-wise comparisons were made by ANOVA with Scheffés post hoc analysis. * $p<0.01$ compared with the value for vehicle-treated cultures not exposed to HB-EGF; ${ }^{*} p<0.01$ compared with values for cultures pretreated with either 0 or $1 \mathrm{ng} / \mathrm{ml}$ HB-EGF and then exposed to the same concentration of kainate. $B$, Cultures were pretreated with $100 \mathrm{ng} / \mathrm{ml} \mathrm{HB}$-EGF for $16 \mathrm{hr}$ and then exposed to vehicle or $10 \mu \mathrm{M}$ kainate. Neuronal survival was assessed at the indicated time points after kainate administration. Values are the mean \pm SEM of determinations made in three separate experiments. Pair-wise comparisons were made by ANOVA with Scheffé's post hoc analysis. ${ }^{*} p<0.01$, ${ }^{* *} p<0.001$ compared with each of the other values at that time point.

HB-EGF mRNA are the result of increased gene transcription rates or message stabilization.

Several findings in the present study suggest that HB-EGF serves an excitoprotective role after seizures. First, levels of HB-EGF mRNA and protein were increased in hippocampus within 3-6 hr of kainate administration. Second, in situ hybridization analysis showed that HB-EGF was increased in cells in the

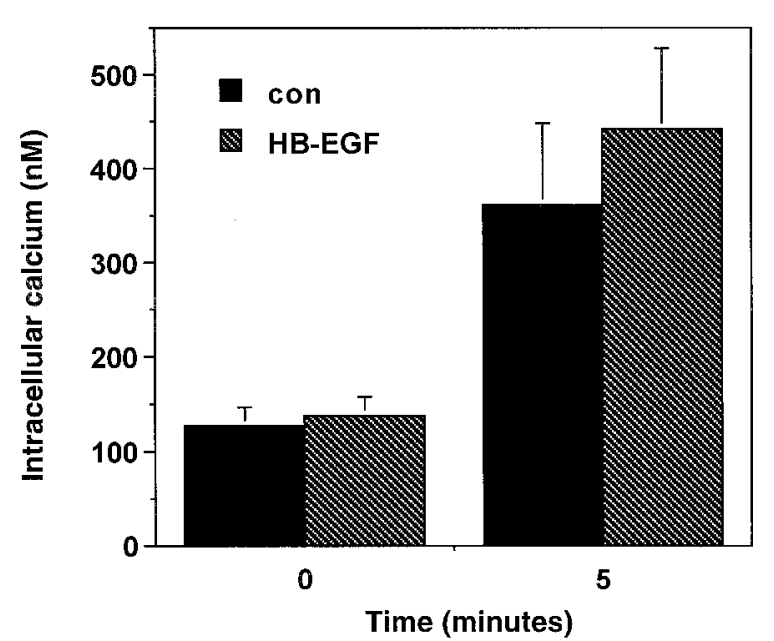

Figure 10. HB-EGF does not affect kainate-induced elevations in $\left[\mathrm{Ca}^{2+}\right]_{\mathrm{i}}$. Hippocampal cultures were pretreated with $100 \mathrm{ng} / \mathrm{ml}$ HB-EGF for $16 \mathrm{hr}$, and the $\left[\mathrm{Ca}^{2+}\right]_{\mathrm{i}}$ in neurons was then determined (time 0 ). Cells were then exposed to $50 \mu \mathrm{M}$ kainate for $5 \mathrm{~min}$, and the $\left[\mathrm{Ca}^{2+}\right]_{\mathrm{i}}$ was again measured in the same neurons. Values are the mean \pm SEM of determinations made in four separate cultures (15-22 neurons per culture).

CA3 and CA1 pyramidal cell layers, cells susceptible to excitotoxic injury. Third, HB-EGF protected cultured hippocampal neurons against kainate toxicity. Collectively, these findings are analogous to previous studies demonstrating that neurotrophic factors induced by insults that include an excitotoxic component (e.g., ischemia) can protect neurons against excitotoxicity (for review, see Mattson, 1996). For example, bFGF, NGF, BDNF, platelet-derived growth factor, and $\mathrm{TNF} \alpha$ are induced by seizures and other insults (Gall and Isackson, 1989; Gall et al., 1991, 1994; Isackson et al., 1991; Dugich-Djordjevic et al., 1992; Rocamora et al., 1992; Iihara et al., 1994; Lauterborn et al., 1994; Riva et al., 1994; Bruce et al., 1996); each factor can protect cultured hippocampal neurons against excitotoxic and metabolic insults (Mattson et al., 1989; Cheng and Mattson, 1991, 1994, 1995; Cheng et al., 1994). Administration of bFGF (Nozaki et al., 1993), GDNF (Martin et al., 1995), NGF (Shigeno et al., 1991), or BDNF (Beck et al., 1994) into the brains of rodents protects neurons against excitotoxic and/or ischemic injury, demonstrating their anti-excitotoxic activities in vivo. Although it remains to be established whether HB-EGF exhibits neuroprotective actions in vivo, its increased expression in response to seizures and its ability to protect cultured neurons against kainate toxicity are consistent with this possibility.

Our cell survival and calcium imaging analyses, in cultured hippocampal neurons exposed to kainate, suggest both similarities and differences in the excitoprotective actions of HB-EGF and other previously characterized neurotrophic factors. Pretreatment for $16 \mathrm{hr}$ with HB-EGF was required for protection against kainate toxicity; shorter pretreatments $(2-6 \mathrm{hr}$ ) were ineffective. This requirement for pretreatment is similar to bFGF (Mattson et al., 1989), BDNF (Cheng and Mattson, 1994), and TNF $\alpha$ (Cheng et al., 1994), which appear to act by altering gene expression. In particular, the neuroprotective mechanisms of bFGF, BDNF, and TNF $\alpha$ appear to involve modulation of the expression of gene products involved in regulation of calcium homeostasis and/or free radical metabolism (Cheng et al., 1994; Mattson et al., 1995). We reported previously that pretreatment of cultured hippocampal neurons with bFGF results in differential 
modulation of calcium responses to activation of NMDA and AMPA/kainate receptors such that NMDA responses are reduced and AMPA/kainate responses enhanced (Cheng et al., 1995). In the present study we found that calcium responses to kainate were neither suppressed nor enhanced in hippocampal neurons pretreated for $16 \mathrm{hr}$ with HB-EGF. Although considerable further work will be required to establish the excitoprotective mechanism of action of HB-EGF, it appears not to result simply from a suppression of kainate-induced elevation of $\left[\mathrm{Ca}^{2+}\right]_{\mathrm{i}}$. Another possible mechanism whereby HB-EGF might protect neurons is by suppressing accumulation of reactive oxygen species. Indeed, it was reported recently that EGF can prevent oxidative stress-induced cell death in cultured cortical neurons (Yamada et al., 1995).

In addition to the potential roles of HB-EGF in seizure responses, the normal postnatal expression of HB-EGF in rat forebrain, and in the cortex in particular, suggests possible roles for this factor in modulating processes such as cell survival, neurite outgrowth, and synaptogenesis. Levels of HB-EGF mRNA were maximal during the early postnatal period, a time during which synaptogenesis is occurring. Previous studies have shown that EGF promotes both cell survival and neurite outgrowth of cultured neocortical neurons (Morrison et al., 1987, 1988; Kornblum et al., 1990). Considering that levels of EGF mRNA and protein are relatively low in cortex during the early postnatal period (Fallon et al., 1984; Kudlow et al., 1989; Lazar and Blum, 1992), and that HB-EGF activates the EGF receptor [which is present at high levels during early brain development (Seroogy et al., 1994, 1995; Kornblum et al., 1997a)], it would not be unlikely that endogenous HB-EGF could regulate neurite outgrowth and synaptogenesis in vivo. Trophic actions on both neurons and glia are also suggested by preliminary in vitro data showing that HB-EGF induces the proliferation of astrocytes and pluripotent precursor cells and increases the survival of neurons derived from the cortex of perinatal rodents (Kornblum et al., 1997b) and induces the tyrosine phosphorylation of EGF-R in primary cultures of rat cerebral astrocytes (Elenius et al., 1997).

Consistent with a role for HB-EGF as a developmental and/or maintenance factor, EGF-R has been detected in both neonatal and adult hippocampus and neocortex (Gomez-Pinilla et al., 1988; Faundez et al., 1992; Tucker et al., 1993; Okano et al., 1996; Seroogy, unpublished data). Expression of HB-EGF persists in the rat neocortex, albeit at relatively low levels, and in hippocampal dentate gyrus in the adult brain. Because of the comparatively low levels of EGF in the adult brain, our data suggest important roles for HB-EGF in both the normal and injured adult CNS. It should be noted that in contrast to our data, Mishima et al. (1996) recently reported widespread expression of HB-EGF in most neuronal and glial cells throughout the normal adult rat brain. Our data strongly suggest a more restricted expression of HBEGF in adult brain consistent with actions on a more limited set of neural populations.

Although little is known about the function of HB-EGF in the CNS, findings in this study implicate various potential roles for HB-EGF in response to limbic seizure activity. Considering that HB-EGF expression has been closely associated with wound healing and tissue repair in many tissues (Marikovsky et al., 1993), it could be predicted that this trophic molecule participates in similar responses in the injured nervous system. Overall, the present findings suggest that HB-EGF serves as an injuryinducible maintenance/neuroprotective factor involved in early cellular responses and tissue remodeling events associated with seizures in the mammalian CNS.

\section{REFERENCES}

Abe K, Xie F-J, Saito H (1991) Epidermal growth factor enhances short-term potentiation and facilitates induction of long-term potentiation in rat hippocampal slices. Brain Res 547:171-174.

Abe K, Ishiyama J, Saito H (1992) Effects of epidermal growth factor and basic fibroblast growth factor on generation of long-term potentiation in the dentate gyrus of fimbria-fornix-lesioned rats. Brain Res 593:335-338.

Abraham JA, Damm D, Bajardi A, Miller J, Klagsbrun M, Ezekowitz AB (1993) Heparin-binding EGF-like growth factor: characterization of rat and mouse cDNA clones, protein domain conservation across species, and transcript expression in tissues. Biochem Biophys Res Commun 190:125-133.

Alexi T, Hefti F (1993) Trophic actions of transforming growth factor- $\alpha$ on mesencephalic dopaminergic neurons developing in culture. Neuroscience 55:903-918.

Barnard JA, Graves-Deal R, Pittelkow MR, DuBois R, Cook P, Ramsey GW, Bishop PR, Damstrup L, Coffey RJ (1994) Auto- and crossinduction within the mammalian epidermal growth factor-related peptide family. J Biol Chem 269:22817-22822.

Barnard JA, Beauchamp RD, Russell WE, Dubois RN, Coffey RJ (1995) Epidermal growth factor-related peptides and their relevance to gastrointestinal pathophysiology. Gastroenterology 108:564-580.

Beck T, Lindholm D, Castrén E, Wree A (1994) Brain-derived neurotrophic factor protects against ischemic cell damage in rat hippocampus. J Cereb Blood Flow Metab 14:689-692.

Ben-Ari Y (1985) Limbic seizures and brain damage produced by kainic acid: mechanisms and relevance to human temporal lobe epilepsy. Neuroscience 14:375-403.

Besner GE, Whelton D, Crissman-Combs MA, Steffen CL, Kim GY, Brigstock DR (1992) Interaction of heparin-binding EGF-like growth factor (HB-EGF) with the epidermal growth factor receptor: modulation by heparin, heparinase, or synthetic heparin-binding HB-EGF fragments. Growth Factors 7:289-296.

Bruce AJ, Boling W, Kindy MS, Peschon J, Kraemer PJ, Carpenter MK, Holtsberg FW, Mattson MP (1996) Altered neuronal and microglial responses to brain injury in mice lacking TNF receptors. Nat Med 2:788-794.

Casper D, Blum M (1995) Epidermal growth factor and basic fibroblast growth factor protect dopaminergic neurons from glutamate toxicity in culture. J Neurochem 65:1016-1026.

Casper D, Mytilineou C, Blum M (1991) EGF enhances survival of dopamine neurons in rat embryonic mesencephalon primary cell culture. J Neurosci Res 30:372-381.

Cheng B, Mattson MP (1991) NGF and bFGF protect rat and human central neurons against hypoglycemic damage by stabilizing calcium homeostasis. Neuron 7:1031-1041.

Cheng B, Mattson MP (1994) NT-3 and BDNF protect CNS neurons against metabolic/excitotoxic insults. Brain Res 640:56-67.

Cheng B, Mattson MP (1995) PDGFs protect hippocampal neurons against energy deprivation and oxidative injury: evidence for induction of antioxidant pathways. J Neurosci 15:7095-7104.

Cheng B, Christakos S, Mattson MP (1994) Tumor necrosis factors protect neurons against excitotoxic/metabolic insults and promote maintenance of calcium homeostasis. Neuron 12:139-153.

Cheng B, Furukawa K, O'Keefe JA, Goodman Y, Kihiko M, Fabian T, Mattson MP (1995) Basic fibroblast growth factor selectively increases AMPA-receptor subunit GluR1 protein level and differentially modulates $\mathrm{Ca}^{2+}$ responses to AMPA and NMDA in hippocampal neurons. J Neurochem 65:2525-2536.

Choi DW (1987) Ionic dependence of glutamate neurotoxicity. J Neurosci 7:369-379.

Cook PW, Damm D, Garrick BL, Wood KM, Karkaria CE, Higashiyama S, Klagsbrun M, Abraham JA (1995) Carboxyl-terminal truncation of leucine76 converts heparin-binding EGF-like growth factor from a heparin-enhancible to a heparin-suppressible growth factor. J Cell Physiol 163:407-417.

Davis KM, Brigstock DR, Johnson PR, Crissman-Combs MA, McCarthy DW, Downing MT, Besner GE (1996) Production of glycosylated heparin-binding EGF-like growth factor in HeLa cells using vaccinia virus. Protein Expr Purif 8:57-67.

Dlugosz AA, Cheng C, Williams EK, Darwiche N, Dempsey PJ, Mann B, 
Dunn AR, Coffey RJ, Yuspa SH (1995) Autocrine transforming growth factor alpha is dispensable for v-rasHa-induced epidermal neoplasia: potential involvement of alternate epidermal growth factor receptor ligands. Cancer Res 55:1883-1893.

Dugich-Djordjevic MM, Tocco G, Lapchak PA, Pasinetti GM, Najm I, Baudry M, Hefti F (1992) Regionally specific and rapid increases in brain-derived neurotrophic factor messenger RNA in the adult rat brain following seizures induced by systemic administration of kainic acid. Neuroscience 47:303-315.

Elenius K, Paul S, Allison G, Sun J, Klagsbrun M (1997) Activation of HER4 by heparin-binding EGF-like growth factor stimulates chemotaxis but not proliferation. EMBO J 16:1268-1278.

Fallon JH, Seroogy KB, Loughlin SE, Morrison RS, Bradshaw RA, Knauer DJ, Cunningham DD (1984) Epidermal growth factor immunoreactive material in the central nervous system: location and development. Science 224:1107-1109.

Faundez V, Krauss R, Holuigue L, Garrido J, Gonzalez A (1992) Epidermal growth factor receptor in synaptic fractions of the rat central nervous system. J Biol Chem 267:20363-20370.

Ferrari G, Toffano G, Skaper SD (1991) Epidermal growth factor exerts neuronotrophic effects on dopaminergic and GABAergic CNS neurons: comparison with basic fibroblast growth factor. J Neurosci Res 30:493-497.

Gall CM, Isackson PJ (1989) Limbic seizures increase neuronal production of messenger RNA for nerve growth factor. Science 245:758-761.

Gall CM, Murray K, Isackson PJ (1991) Kainic acid-induced seizures stimulate increased expression of nerve growth factor mRNA in rat hippocampus. Mol Brain Res 9:113-123.

Gall CM, Berschuer R, Isackson PJ (1994) Seizures increase basic fibroblast growth factor mRNA in adult rat forebrain neurons and glia. Mol Brain Res 21:190-205.

Giusti P, Gusella M, Lipartiti M, Milani D, Zhu W, Vicini S, Manev H (1995) Melatonin protects primary cultures of cerebellar granule neurons from kainate but not from $N$-methyl-D-aspartate excitotoxicity. Exp Neurol 131:39-46.

Gomez-Pinilla F, Knauer DJ, Nieto-Sampedro M (1988) Epidermal growth factor receptor immunoreactivity in rat brain. Development and cellular localization. Brain Res 438:385-390.

Grynkiewicz G, Poenie M, Tsein RY (1985) A new generation of calcium indicators with greatly improved fluorescence properties. J Biol Chem 260:3440-3450.

Higashiyama S, Abraham JA, Miller J, Fiddes JC, Klagsbrun M (1991) A heparin-binding growth factor secreted by macrophage-like cells that is related to EGF. Science 251:936-939.

Higashiyama S, Lau K, Besner GE, Abraham JA, Klagsbrun M (1992) Structure of heparin-binding EGF-like growth factor. J Biol Chem 267:6205-6212.

Hughes P, Beilharz E, Gluckman P, Dragunow M (1993) Brain-derived neurotrophic factor is induced as an immediate early gene following $N$-methyl-D-aspartate receptor activation. Neuroscience 57:319-328.

Humpel C, Lippoldt A, Chadi G, Ganten D, Olson L, Fuxe K (1993) Fast and widespread increase of basic fibroblast growth factor messenger RNA and protein in the forebrain after kainate-induced seizures. Neuroscience 57:913-922.

Humpel C, Hoffer B, Strömberg I, Bektesh S, Collins F, Olson L (1994) Neurons in the hippocampal formation express glial cell line-derived neurotrophic factor messenger RNA in response to kainate-induced excitation. Neuroscience 59:791-795.

Iihara K, Sasahara M, Hashimoto N, Uemura Y, Kikuchi H, Hazama F (1994) Ischemia induces the expression of platelet-derived growth factor-B chain in neurons and brain macrophages in vivo. J Cereb Blood Flow Metab 14:818-824.

Isackson PJ, Huntsman MM, Murray KD, Gall CM (1991) BDNF mRNA expression is increased in adult rat forebrain after limbic seizures: temporal patterns of induction distinct from NGF. Neuron 6:937-948.

Kim GY, Besner GE, Steffen CL, McCarthy DW, Downing MT, Luquette MH, Abad MS, Brigstock DR (1995) Purification of heparinbinding epidermal growth factor-like growth factor from pig uterine luminal flushings, and its production by endometrial tissues. Biol Reprod 52:561-571.

Kornblum HI, Raymon HK, Morrison RS, Cavanaugh KP, Bradshaw RA, Leslie FM (1990) Epidermal growth factor and basic fibroblast growth factor: effects on an overlapping population of neocortical neurons in vitro. Brain Res 535:255-263.
Kornblum HI, Gall CM, Seroogy KB, Lauterborn JC (1995) A subpopulation of striatal GABAergic neurons expresses the epidermal growth factor receptor. Neuroscience 69:1025-1029.

Kornblum HI, Hussain RJ, Bronstein JM, Gall CM, Lee DC, Seroogy KB (1997a) Prenatal ontogeny of the epidermal growth factor receptor and its ligand, transforming growth factor alpha, in the rat brain. J Comp Neurol 380:243-261.

Kornblum HI, Zurcher SD, Miettinen PJ, Wiesen J, Werb Z, Derynck R, Opanashuk L, Seroogy KB (1997b) Heparin-binding epidermal growth factor: effects on pluripotent precursors, neurons, and astrocytes from the CNS. Soc Neurosci Abstr 23:890.

Kudlow JE, Leung AW, Korbin MS, Paterson AJ, Asa SL (1989) Transforming growth factor $\alpha$ in the mammalian brain. J Biol Chem 264:3880-3883.

Lauterborn JC, Isackson PJ, Gall CM (1994) Seizure-induced increases in NGF mRNA exhibit different time courses across forebrain regions and are biphasic in hippocampus. Exp Neurol 125:22-40.

Lauterborn JC, Rivera S, Stinis CT, Hayes VY, Isackson PJ, Gall CM (1996) Differential effects of protein synthesis inhibition on the activity-dependent expression of BDNF transcripts: evidence for immediate-early gene responses from specific promoters. J Neurosci 16:7428-7436.

Lazar LM, Blum M (1992) Regional and developmental expression of epidermal growth factor and transforming growth factor mRNA in mouse brain by a quantitative nuclease protection assay. J Neurosci 12:1688-1697.

Marikovsky M, Breuing K, Liu PY, Eriksson E, Higashiyama S, Farber P, Abraham J, Klagsbrun M (1993) Appearance of heparin-binding EGF-like growth factor in wound fluid as a response to injury. Proc Nat Acad Sci USA 90:3889-3893.

Mark RJ, Hensley K, Butterfield DA, Mattson MP (1995) Amyloid $\beta$-peptide impairs ion-motive ATPase activities: evidence for a role in loss of neuronal $\mathrm{Ca}^{2+}$ homeostasis and cell death. J Neurosci 15:6239-6249.

Martin D, Miller G, Rosendahl M, Russell DA (1995) Potent inhibitory effect of glial cell line-derived neurotrophic factor against kainic acid mediated seizures in the rat. Brain Res 683:172-178.

Marty S, Dusart I, Peschanski M (1991) Glial changes following an excitotoxic lesion in the CNS-I. Microglia/macrophages. Neuroscience 45:529-539.

Mattson MP (1996) Neuroprotective signal transduction: relevance to stroke. Neurosci Biobehav Rev 21:193-206.

Mattson MP, Lindvall O (1997) Neurotrophic factor and cytokine signaling in the aging brain. In: The aging brain, Advances in cell aging and gerontology, Vol 2 (Mattson MP, Geddes JW, eds), pp 299-345. Greenwich, CT: Jai Press.

Mattson MP, Scheff SW (1994) Endogenous neuroprotection factors and traumatic brain injury: mechanisms of action and implications for therapies. J Neurotrauma 11:3-33.

Mattson MP, Murrain M, Guthrie PB, Kater SB (1989) Fibroblast growth factor and glutamate: opposing actions in the generation and degeneration of hippocampal neuroarchitecture. J Neurosci 9:3728-3740.

Mattson MP, Tomaselli K, Rydel RE (1993) Calcium-destabilizing and neurodegenerative effects of aggregated $\beta$-amyloid peptide are attenuated by basic FGF. Brain Res 621:35-49.

Mattson MP, Barger SW, Begley JG, Mark RJ (1995) Calcium, free radicals, and excitotoxic neuronal death in primary cell culture. Methods Cell Biol 46:187-216.

Mazzoni IE, Kenigsberg RL (1994) Localization and characterization of epidermal growth-factor receptors in the developing medial septal area in culture. Brain Res 656:115-126.

Mishima K, Higashiyama S, Nagashima Y, Miyagi Y, Tamura A, Kawahara N, Taniguchi N, Asai A, Kuchino Y, Kirino T (1996) Regional distribution of heparin-binding epidermal growth factor-like growth factor mRNA and protein in adult rat forebrain. Neurosci Lett 213:153-156.

Morgan TE, Nichols NR, Pasinetti GM, Finch CE (1993) TGF- $\beta 1$ mRNA increases in macrophage/microglial cells of the hippocampus in response to deafferentation and kainic acid-induced neurodegeneration. Exp Neurol 120:291-301.

Morrison RS, Kornblum HI, Leslie FH, Bradshaw RA (1987) Trophic stimulation of cultured neurons from neonatal rat brain by epidermal growth factor. Science 238:72-75.

Morrison RS, Keating RF, Moskal JR (1988) Basic fibroblast growth 
factor and epidermal growth factor exert differential trophic effects on CNS neurons. J Neurosci Res 21:71-79.

Nadler JV, Perry B, Cotman CW (1978) Intraventricular kainic acid preferentially destroys hippocampal pyramidal cells. Nature 271:676-677.

Nozaki K, Finklestein SP, Beal MF (1993) Basic fibroblast growth factor protects against hypoxia-ischemia and NMDA neurotoxicity in neonatal rats. J Cereb Blood Flow Metab 13:221-228.

Okano HJ, Pfaff DW, Gibbs RB (1996) Expression of EGFR-, p75NGFR-, and PSTAIR (cdc2)-like immunoreactivity by proliferating cells in the adult rat hippocampal formation and forebrain. Dev Neurosci 15:199-209.

Ono M, Raab G, Lau K, Abraham JA, Klagsbrun M (1994) Purification and characterization of transmembrane forms of heparin-binding EGFlike growth factor. J Biol Chem 269:31315-31321.

Opanashuk LA, Numan S, Seroogy KB (1995) Expression of heparinbinding epidermal growth factor (HB-EGF) mRNA in rat brain. Soc Neurosci Abstr 21:2011.

Park TH, Mytilineau C (1992) Protection from 1-methyl-4phenylpyridinium $\left(\mathrm{MPP}^{+}\right)$toxicity and stimulation of regrowth of $\mathrm{MPP}^{+}$-damaged dopaminergic fibers by treatment of mesencephalic cultures with EGF and basic FGF. Brain Res 599:83-97.

Polihronis M, Murphy BF, Pearse MJ, Power DA (1996) Heparinbinding epidermal growth factor-like growth factor, an immediate-early gene for mesangial cells, is up-regulated in the Thy-1.1 model. Exp Nephrol 4:271-278.

Raab G, Higashiyama S, Hetelekidis S, Abraham JA, Damm D, Ono M, Klagsbrun M (1994) Biosynthesis and processing by phorbol ester of the cell surface-associated precursor form of heparin-binding EGF-like growth factor. Biochem Biophys Res Commun 204:592-597.

Riva MA, Donati E, Tascedda F, Zolli M, Racagni G (1994) Short- and long-term induction of basic fibroblast growth gene expression in rat central nervous system following kainate injection. Neuroscience 59:55-65.

Rocamora N, Palacios JM, Mengod G (1992) Limbic seizures induce a differential regulation of the expression of nerve growth factor, brainderived neurotrophic factor, and neurotrophin-3 in the rat hippocampus. Mol Brain Res 13:27-33.

Schneider JS, DiStefano L (1995) Enhanced restoration of striatal dopamine concentrations by combined GM1 ganglioside and neurotrophic factor treatments. Brain Res 674:260-264.

Seroogy KB, Herman JP (1997) In situ hybridization approaches to the study of the nervous system. In: Neurochemistry: A practical approach, Ed 2 (Turner AJ, Bachelard HS, eds), pp 121-150. Oxford: IRL.

Seroogy KB, Han VKM, Lee DC (1991) Regional expression of transforming growth factor- $\alpha$ mRNA in the rat central nervous system. Neurosci Lett 125:241-245.
Seroogy KB, Lundgren KH, Lee DC, Guthrie KM, Gall CM (1993) Cellular localization of transforming growth factor- $\alpha$ mRNA in rat forebrain. J Neurochem 60:1777-1782.

Seroogy KB, Numan S, Gall CM, Lee DC, Kornblum HI (1994) Expression of EGF receptor mRNA in rat nigrostriatal system. NeuroReport 6:105-108.

Seroogy KB, Gall CM, Lee DC, Kornblum HI (1995) Proliferative zones of postnatal rat brain express epidermal growth factor receptor mRNA. Brain Res 670:157-164.

Shigeno T, Mima T, Takakura K, Graham DI, Kato G, Hashimoto Y, Furukawa S (1991) Amelioration of delayed neuronal death in the hippocampus by nerve growth factor. J Neurosci 11:2914-2919.

Sperk G (1994) Kainic acid seizures in the rat. Prog Neurobiol 42:1-32.

Sperk G, Lassmann H, Baran H, Kish SJ, Seitelberger F, Hornykiewicz O (1983) Kainic acid induced seizures: neurochemical and histopathological changes. Neuroscience 10:1301-1315.

Tan MS, Tsai JC, Lee YJ, Chen HC, Shin SJ, Lai YH, Perrella MA, Bianchi C, Higashiyama S, Endege W (1994) Induction of heparinbinding epidermal growth factor-like growth factor mRNA by protein kinase $\mathrm{C}$ activators. Kidney Int 46:690-695.

Terlau H, Seifert W (1989) Influence of epidermal growth factor on long-term potentiation in the hippocampal slice. Brain Res 484:352-356.

Tucker MS, Khan I, Fuchs-Young R, Price S, Steininger TL, Greene G, Wainer BH, Rosner MR (1993) Localization of immunoreactive epidermal growth factor receptor in neonatal and adult rat hippocampus. Brain Res 631:65-71.

Watanabe T, Shintani A, Nakata M, Shing Y, Folkman J, Igarashi K, Sasada R (1994) Recombinant human betacellulin. Molecular structure, biological activities, and receptor interaction. J Biol Chem 269:9966-9973.

Yamada M, Enokido Y, Ikeuchi T, Hatanaka H (1995) Epidermal growth factor prevents oxygen-triggered apoptosis and induces sustained signalling in cultured rat cerebral cortical neurons. Eur J Neurosci 7:2130-2138.

Yamada M, Ikeuchi T, Hatanaka H (1997) The neurotrophic action and signalling of epidermal growth factor. Prog Neurobiol 51:19-37.

Yoshizumi M, Kourembanas S, Temizer DH, Cambria RP, Quertermous T, Lee ME (1992) Tumor necrosis factor increases transcription of the heparin-binding epidermal growth factor-like growth factor gene in vascular endothelial cells. J Biol Chem 267:9467-9469.

Zafra F, Castrén E, Thoenen H, Lindholm D (1991) Interplay between glutamate and gamma-aminobutyric acid transmitter systems in the physiological regulation of brain-derived neurotrophic factor and nerve growth factor synthesis in hippocampal neurons. Proc Natl Acad Sci USA 88:10037-10041. 